Весна Арсић

Бранка Драгосавац

Библиотека града Београда
UDC: 001.811:174

DOI: 10.18485/dh.2015.2.ch11

\title{
ДИГИТАЛИЗАЦИЈА И СТАНДАРДИЗАЦИЈА ЦИТИРАњА
}

\section{Сажетак}

Овај рад се бави једном врстом запостављене проблематике која приликом одређених научних истраживања сваки пут изнова искрсне. Ново доба и другачији начин комуникације - електронски, једноставнији и бржи иницирало је и другачији начин научних истраживања која се заснивају и на најновије истраживачке изворе дигиталне. Позитивне стране такве врсте истраживања су исто тако и једноставније и брже истраживање грађе која је лако доступна у било које време и на било ком географском простору. Тако је са новим, дигиталним добом распрострањен и нови, дигитални начин истраживања. Дигитални извори који нису настали (рођени) у дигиталној форми, већ су настали дигитализацијом материјалних, аутентичних докумената, осим чувања одређене грађе, нарочито архивске, од пропадања, и уштеде простора, свакако обезбеђују и доступност, што је у складу са тенденцијама свих научно-истраживачких институција, па и појединаца. Чак се и ригорозна ауторска и сродна права све више либерализују у том смислу у научним областима, за сада највише у европским државама. On line извори су све заступљенији у фуснотама и литератури научних радова, и сходно томе, стандардизован је и начин цитирања и навођења литературе у сва четири позната стила цитирања. Ипак, до потпуне дигитализације проћи ће још много година, а за то време и много још недигитализоване архивске грађе није доступно широј истраживачкој јавности. У међувремену, нарочито старији истраживачи, немају ослонац у стандардима за навођење архивске грађе. За сада се начин цитирања архивске грађе своди на правила појединачних архива (ознаке сигнатура у одређеним архивима) или на препоруке на форумима, као што је пронађен, такође на интернету, један који потиче из Истраживачке станице Петница на форуму My city mreže, још од пре 10 година. Дигитализована грађа је одговорила изазовима дигиталне хуманистике, али, до окончања овог заиста вредног процеса за науку и цивилизацију уопште, не би се смеле губити везе са аутентичношћу архивске грађе, што се већ одразило недостатком у стандардизацији цитирања, које представља неизоставан елемент сваког добро аргументованог научног рада.

Кључне речи (до десет) на матерњем језику: дигитализација, дигитални извори, научно истраживање, стандарди, цитирање, архивска грађа 


\section{Дигитализација и стандардизација цитирања}

Текст Да ли је Гугл добар за историју? Повратак случају Пипс, сажета је илустрација суштински добрих и лоших страна дигитализације. Објављен је у марту 2010. године на сајту Центра за дигиталне хуманистичке науке. Аутор је Витни Третиен, тада докторанд на Катедри за енглески језик Универзитета Дјук у САД, данас доцент дигиталних хуманистичких наука на Универзитету Северна Каролина Чепел Хил. То је, заправо, прича о открићима до којих је дошла приликом истраживања за писање коауторског де̂ла есеја о ремедијацији, дисмедијацији и немедијацији на примеру Дневника Семјуела Пипса.

Легендарна је прича о Џону Смиту, сиромашном намученом студенту који је (како каже прича) провео три године, од 1819. до 1822, анализирајући рукопис Дневника, не знајући да „кључ” за „дешифровање” лежи на полици библиотеке, „на само пар корака од места на којем је радио". Витни Третиен описује како је на основу биографије коју је написала Алис Госен 1904. године и помоћу Гугл књига дошла, између осталог, и до два факсимила плана за транскрипцију Дневника који датирају пре Смита, што оповргава устаљену легенду о његовом настанку и указује на чињеницу да ово дело није било сасвим непознато пре него што је Смит приступио свом узалудном и мукотрпном послу. „Ово истраживање - једна узбудљива алтернативна историја канонске приче - не би била могућа без Гугл књига или сличног интернет претраживача и базе текстова са оптичким препознавањем знакова. Онда, да ли је Гугл добар за историју? Ух, и те како. То би до сад требало да се подразумева“, напомиње Витни Третиен. ${ }^{1}$

Међутим, ту није крај приче. Да би илустровала свој есеј, ауторка је направила дигиталне фотографије факсимила из биографије ауторке Алис Госен. Приликом тражења дозвола, уочено је да је резолуција скенова неодговарајућа за штампу, па је наручила да јој из складишта Универзитета Дјук донесу велику прашњаву књигу из 1904. године да би сама скенирала слике. Испоставило се да је оно

1 Whitney Trettien, „Да ли је Гугл добар за историју? Повратак случају Пипс,“ Центар за дигиталне хуманистичке науке, датум објављивања 21. марта 2010, http://www. humanistika.org/?p=348. 
за шта је мислила да су огреботине од скенера или нека друга врста минијатурног оштећења површине хартије - биле целе странице. Неком ко је скенирао текст за Гугл књиге није пало на памет да отвори папир; „а пошто Гугл књиге немају никакав механизам да на својим пљоснатим скеновима укажу на покретне делове и странице које се отварају, оно што је било сакривено унутар савијених страна је за базу података изгубљено“.2

На крају, Витни Третиен закључује: „Као и сви медији, алатке попут Гугл књига неизбежно (пре)уобличавају наша истраживања, отварајући нам узбудљиве нове могућности; али, док то чине, друге могућности се затварају. Осим што имају неблаготворан ефекат на истраживање кодекса као форме, одсуства у дигиталним архивима стварају слику „културе штампе” која обесхрабрујуће клизи ка веома редуктивним моделима које последњих година многи историчари књиге доводе у питање. Дошло је време да размишљамо о томе како скенирање посредује у преношењу материјалности текста и како нам базе података и њихове структуре не дозвољавају да документујемо неке књишке аномалије. Иако овај случај све у свему није ослабио мој аргумент, он ће ме натерати да следећи пут добро размислим када приметим неку чудну малу огреботину на Гугл књигама“.”

Ова прича нам поставља питање: Шта нам (добро) доноси дигитализација, а шта неповратно губимо, посебно у хуманистичким наукама?

Данас, у XXI веку, технологија је толико усавршена да више не представља само подршку или помоћно средство у истраживањима, већ „ствара окружења и алате за производњу, организовање, надгледање и интеракцију са знањем које се „рађа дигитално“ и живи у разним дигиталним контекстима“. 4

Чињеница је, и то се не може порећи, да је дигитално доба променило начин комуникације и научних истраживања. Све се одвија брзо, једноставно, ефикасно, јефтино. Интернет је учинио доступ-

\footnotetext{
2 Ibid.

3 Ibid.

4 David M. Berry, “Дигитална хуманистика: први, други, трећи талас," Центар за дигиталне хуманистичке науке, датум објављивања 5. марта 2011, http://www.humanistika.org/?p=487.
} 
ним небројена научна достигнућа, у свако доба. Свако ко има бар мало истраживачког духа, може да се упусти у неограничене авантуре задовољавања своје радозналости. Али, да ли то могу себи да дозволе и истраживачи који трагају за научним аргументима? Примера ради, ако се на Гугл претраживачу укуца Семјуел Пипс, добиће ce 1.550 .000 резултата. Наравно, не односе се сви на аутора чувених дневника из 17. века, већ и на фејсбук странице, игре, библиотеку или појмове који садрже једну од ове две речи које чине име и презиме. Са дигитализацијом и брзом и лаком доступношћу, следи суочавање истовремено и са обиљем истих, сличних или сасвим различитих појмова и чињеница, које и не морају да буду сасвим поуздане. Превише информација, такође, може да доведе до ситуације да се неко посвети „дешифровању“ неке области чије је разрешење „одмах на полици изнад“, једнако као и да нема интернет и игром случаја не зна за два факсимила која су већ разрешила проблем којим се бави. Наравно, са познавањем поузданих дигиталних база и употребом филтера лакше је проналажење у понуђеном обиљу података, али се и даље располаже са мало мањим мноштвом чињеница које треба прегледати. Тако да се, уз одредницу Семјуел Пипс, додавањем ограничења на 17. век, смањује број резултата на 1.120.000, а додавањем и речи дневници, смањиће се на 9.370.

Неспорне су предности дигитализације које доприносе брзини, великој уштеди папира, због чега су поштеђене шуме, „плућа наше планете“, као и простора за смештај „папирног“ материјала. Овај рад се неће позабавити најновијом документацијом, која је настала као дигитална, мада није сигурно да ли она има дужи рок трајања у односу на папирну. Дигитализација папирне грађе свакако помаже при очувању старих и ретких књига. Такође, доступност дигиталних облика је све већа, с обзиром на учестале расправе по питању ауторских права, које воде ка либерализацији доступности научних достигнућа. ${ }^{5}$ Једно од питања које се намеће при истраживању и проучавању докумената, списа или рукописа је стандардизација цитирања. Свако

5 Рајнер Кулен, проф. Информатичких наука на Одсеку за компјутерске и информатичке науке Универзитета у Констанцу, Немачка, одржао је предавање „Шта очекујемо од реформе европског ауторског права из перспективе образовања, науке $и$ библиотекарства?“” у Народној библиотеци Србије 24. јуна 2015. године. 
ко је писао и објављивао текстове и књиге о одређеним научним областима зна да сваки писани рад садржи и списак литературе, као и фусноте, односно на српском језику већ заборављену реч - подбелешке. ${ }^{6}$ Прописани су међународни стандарди за библиографско цитирање различитих извора грађе. Универзитетска библиотека „Светозар Марковић“ у Београду на свом сајту представља осам стилова цитирања који су најчешће у употреби: APA стил, Чикаго, MLA, AMA, NLM, CSE/CBE, Харвард и Оксфорд, ${ }^{7}$ а Библиотека Дома културе Студентски град на свом сајту нуди „Водич за цитирање“ у коме објашњава и презентује четири: APA, MLA, Чикаго и CSE. ${ }^{8}$ Такође, Гугл сколар и Зотеро дају основне информације, најчешће илустроване примерима, за већину стилова цитирања различитих извора.

Сваки од ових стилова има своју превасходну заступљеност у одређеним научним областима, а онај који се најчешће примењује у друштвеним и хуманистичким наукама је Чикаго стил. MLA се највише користи у књижевности и лингвистици, АРА у друштвеним наукама, а Оксфорд такође у хуманистици, али ређе код нас.

Међутим, претрагом свих наведених примера у сваком стилу појединачно, као и претрагом на интернету преко кључне речи, нису нађени прописани стандарди за навођење изворне архивске грађе коришћене при истраживању. Наведени су примери фуснота и референсних страна за цитирање из књига са једним, два, три и више аутора, зборника радова, часописа, магазина, новина, различитих електронских извора, али ниједан пример не постоји за цитирање приликом коришћења архивске документације из које потичу дате информације.

Према Закону о културним добрима, „архивску грађу чине изворни и репродуковани писани, цртани, компјутеризовани, штампани, фотографисани, филмовани, микрофилмовани, фонографисани или на други начин забележни документарни материјал од посебног

6 „Упутство за припрему рукописа за штампу, Јужнословенски филолог LXV (2009): 656-657, https://books.google.rs/books?id.

7 Универзитет у Београду Универзитетска библиотека „Светозар Марковић“, „Цитирање литературе и библиографски алати," последњи пут ажурирано 11. августа 2015, http:// unilib.libguides.com/content.php?pid=441025\&sid=3611085.

8 Дом културе Студентски град, „Библиотека Дксг - Водич за цитирање,“ http://www. dksg.rs/biblioteka/vodicZaCitiranje/uvod.html, приступ сајту 5. августа 2015. 
значаја за науку и културу који је настао у раду државних органа и организација, органа јединица територијалне аутономије и локалне самоуправе, политичких организација и њихових органа, установа и других организација, верских заједница, као и појединаца, без обзира на то кад је и где настао и да ли се налази у установама заштите или ван њих“. ${ }^{9}$ Проблем настаје код „изворног документарног материјала“, који се проучава на старомодан начин, на лицу места, у одређеној институцији у којој је смештен и чија је ознака углавном интерна сигнатура и ознака за кутију, фасциклу или свежањ.

Претраживањем сајтова Архива Југославије, Архива Србије и Архива Београда, као и директним контактом са запосленима у тим институцијама, пронађена су два документа која су најближа утврђивању чињеница о цитирању архивске грађе. Један је ISAD (G) Опити међународни стандард за опис архивске грађе, ${ }^{10}$ а други Стандарди и препоруке које се односе на делатности у архиву. ${ }^{11}$

ISAD (G) Опити међународни стандард за опис архивске грађе „садржи опште смернице за израду архивских описа које треба користити заједно са постојећим националним стандардима или као основу за израду националних стандарда“. ${ }^{12}$ Осим упућивања на додатне стандарде, у последњој, 15. тачки, наведено је најзанимљивије усмерење: „За навођење објављеног извора у било којем елементу описа, треба користити најновију верзију ISO 690 Документација - Библиографске упутнице - Садржај, форма и структура (Documentation - Bibliographic references - Content, form and structure) “. ${ }^{13}$

9 Народна библиотека Србије, Закони, „Закон о културним добрима,“ (Службени гласник PC", бр. 71/94), приступ сајту 5. августа 2015, https://www.nb.rs/view_file. php?file_id=286

10 International Council of Archives, "ISAD (G) Општи међународни стандард за опис архивске грађе," http://www.ica.org/download.php?id=1695, приступ сајту 6. августа 2015.

11 Оливера Порубовић-Видовић и Сузана Срндовић, „Стандарди и препоруке које се односе на делатности у архиву," Архив, часопис Архива Србије и Црне Горе, 1-2 (2007): 9-26, http://www.arhivyu.gov.rs/index.php?

12 International Council of Archives, „ISAD (G) Општи међународни стандард за опис архивске грађе," Увод, стр. 11, http://www.ica.org/download.php?id=1695, приступ сајту 6. августа 2015.

13 International Council of Archives, „ISAD (G) Општи међународни стандард за опис архивске грађе," Увод, стр. 13, http://www.ica.org/download.php?id=1695, приступ сајту 6. августа 2015. 
Управо та, најновија верзија ISO 690 стандарда Документација - Библиографске упутнице - Садржај, форма и структура (Documentation - Bibliographic references - Content, form and structure) пронађена је на сајту Архива Југославије, са објашњењем да „дефинише начин описивања библиографских јединица (књига, часописа, чланка, патентне документације и др.) приликом израде библиографија, библиотечких каталога, индекса, цитирања у научним и стручним радовима и др.“, са позивањем на претходни ISO 690:1975 који је еквивалентан eqv SRPS Z. A4.023:1981. ${ }^{14}$ Приликом претраживања наведени стандард није нађен у форми у којој може да се отвори и прегледа садржина тог документа.

У тексту Стандарди и препоруке које се односе на делатности у архиву 15 аутори Оливера Порубовић-Видовић и Сузана Срндовић су детаљно побројале и описале намену општих стандарда, оних који се односе на информационе технологије, архивистику и библиотекарство, а у оквиру смештаја, чувања и излагања, као и техничке заштите библиотечке и архивске грађе и међународне и националне стандарде. Али све се односи на опис (архивске) грађе, а не на прописана, чврсто утемељена правила цитирања са тачно одређеним редоследом елемената и знаковима интерпункције, као што је то наведено у свим стиловима цитирања за различите изворе, које смо већ споменули. Не треба занемарити ни податак да наднаслов изнад првог поглавља Општи стандарди гласи Препоруке. У директном контакту са једном службеницом Института за стандардизацију Србије, између осталих, добијена је и информација да су у суштини „сви стандарди на нивоу препорука“. Могуће је да ова примедба постоји због често навођене напомене да се правила цитирања евентуално могу мењати у складу са интерним правилима издавача.

У свом тексту, др Драгана Сабовљев из Градске народне библиотеке „Жарко Зрењанин“ у Зрењанину, објављеном у 13. броју Пан-

14 Архив Југославије, „ISO 999:1996 Information and documentation - Guidelines for the content, organization and presentation of indexes", http://www.arhivyu.gov.rs/active/ sr-cyrillic/home/glavna_navigacija/za_arhiviste/standardi/opsti_standardi.html, приступ сајту 6. августа 2015.

15 Оливера Порубовић-Видовић и Сузана Срндовић, „Стандарди и препоруке које се односе на делатности у архиву,“ Архив, часопис Архива Србије и Црне Горе, 1-2 (2007): 9-26, http://www.arhivyu.gov.rs/index.php? 
чевачког читалишта, под називом Чикаго стил библиографрског цитирањ ${ }^{16}$ до сада најобухватније детаљно образлаже и илуструје примерима врсте грађе које се наводе као извор. Али ни овде нема примера за архивску грађу. Можда су најближи и најлогичнији за примену цитирања архивске грађе примери који се односе на документе извршних владиних органа:

„Ф: редни број. Име министарства, Наслов текста, Име и презиме аутора (Место издања: Издавач, година) http://adresa (преузето датум)

Б: Име министарства. Наслов текста. Име и презиме аутора. Место издања: Издавач, година. http: //adresa (преузето датум)“17

Пример Ф означава модел за фусноту, а Б за библиографију. Наравно, овде су узети у обзир свакако дигитализовани примери, јер се могу наћи на интернету. Ни у тексту Наташе Милић, Цитирање литературе у научном раду, ${ }^{18}$ нису пронађени примери цитирања архивске грађе.

Професор др Никола Сузић на крају свог текста Правила писања научног рада: АПА и други стандарди образлаже: „Не постоји српски, хрватски или неки други стил цитирања на Балкану. Код нас је до сада владао, а и данас преовлађује, хаос у цитирању и навођењу извора. Није риједак случај да у раду једног аутора срећемо више стилова цитирања, да се чак у истој листи радова препозна више од два стила цитирања. Угледни часописи и аутори до сада су се трудили да овакав хаос не дозволе у својим радовима, али им је посао био отежан тиме што нису имали јасан и сигуран водич, јасан сет правила који би им омогућио да слиједе одабрани стил цитирања“. ${ }^{19}$ Пробле-

16 Драгана Сабовљев, „Чикаго стил библиографског цитирања,“ Панчевачко читалиште, часопис Градске библиотеке Панчево, 13 (2008): 111 - 115, http://www.citaliste.rs/citaliste_files/sabovljev_cikago_stil.pdf часопис Градске библиотеке Панчево, 13 (2008): 111-115, http://www.citaliste.rs/citaliste_files/sabovljev_cikago_stil.pdf Наташа Милић, „Цитирање литературе у научном раду,“ Ју Народна и универзитетска библиотека Републике Српске, http://nub.rs/fileadmin/informacione_usluge/citiranje/ Natasa_Milic-Citiranje_literature_u_naucnom_radu.pdf, приступ сајту 7. августа 2015. Никола Сузић, „Правила писања научног рада: АПА и други стандарди,“ Panevropski Apeiron univerzitet, https://www.google.rs/search?q=nikola+suzi\%C4\%87\&sitesearch=ap eiron-uni.eu\&gws_rd=cr,ssl\&ei=IGvQVdGhK8i6UY67gJgL, приступ сајту 7. августа 2015. 
ми цитирања грађе на српском језику, односно на Балкану, који су овде наведени су друге природе. Али важна је примедба у вези са неусклађеностима и недоследностима приликом цитирања да је разлог „недостатак јасног и сигурног водича, сета правила“. Без обзира на чињеницу да нису спомињани примери за цитирање архивске грађе, закључује се да је проблематика стандардизације цитирања шира од недостатка правила за цитирање једне врсте извора. Углавном је реч о мањкавостима појединих стилова, на примеру Чикаго стила, које доприносе недоследности и уносе забуну у одређеним ситуацијама.

Ипак, у даљим трагањима за стандардом, односно документом који би представљао прописани стил цитирања изворне архивске грађе за фусноте и навођење референсне литературе дошло се и до сајта Му city мреже са текстом Истраживачке станице Петница, објављеним још 6. јуна 2005. године, који „служи за правилно навођење литературе при писању научно-истраживачких радова, ... осим када та установа за коју пишете изричито не захтева другачије“. ${ }^{20}$

Наводи се само део који се односи на архивску грађу, уз напомену да је то једино „правило“ на српском језику за цитирање архивске грађе као извора, које је незванично и на нивоу препоруке.

„ІІ извори:

1) архивска грађа:

*Грађа у архивима је организована у целине. Подаци о извору се наводе по организационој хијерархији:

Институција, фонд, одељење, кутија, фасцикла, документ, страна -пример: Архив Југославије, фонд Министарство унутрашњих дела Краљевине Југославије (14), фасцикла 232, лист бр. 421. (у даљем тексту: AJ, 14, Ф-232, 421).

Приликом првог позивања на одредницу она се наводи у целости, а касније скраћено: AJ, 14, Ф-232, 421.

-Није у сваком архиву грађа сређена на исти начин. Ово су два примера како се наводи грађа из других архива:

-Војни архив, пописник Ратна архива армија и армијских области 1914-1920, Трећа армијска област (4/III), кутија 55, фасцикла 12, документ бр. 25/1-3/ (скраћено: ВА, П-4/III, К-55, Ф-12, Бр. 25/1-3).

20 My City mreža, „Правила и примери навођења литературе и извора,“ 2005, http:// www.mycity.rs/Istorija/Pravila-i-primeri-navodjenja-literature-i-izvora.html\#p170822 
-Архив Србије, фонд Југословенски добровољци у Русији (89), несређен, фасцикла 9. (скраћено: АС, 89, Ф-9). Тамо где грађа у оквиру фонда није сређена наводи се само број фонда и број фасцикле.

-Дужина одреднице може варирати у зависности од организационих целина, сређености архива, итд. па може садржати само назив институције и инвентарски број документа (пример: Завичајни музеј Земуна, инв.(ентарски) бр.(ој) 2657. Ако је у питању рукопис, односно необјављен рад, могуће је и следеће решење: Марковић, Иван, Први светски рат и предратно време у Земуну од 1908. до 1918. године према писању локалне штампе, рукопис у Завичајном музеју Земуна, инв. бр. 2227.).

1a) зборници грађе: "Записник са седнице Привредног савета одржане 6. и 8. октобра 1945. године", Привредна политика Владе ФНРЈ. Записници Привредног савета Владе ФНРЈ 1944-1953 І, Архив Југославије, Београд 1955, 31“. ${ }^{21}$

Часопис Радови Завода за хрватску повијест Филозофског факултета Свеучилишта у Загребу у броју 29 од 1996. године објавио је Упуте сурадницима у којима наводи да „због штедње простора редакција (je) од идућег броја одлучила увести начин цитирања који је сличан оном који се практично учестало користи у иноземству“. На крају Упуте Уредништво редакције пише: „За цитирање необјављене архивске грађе правило је да се у биљешци име фонда и серије наведе као кратица, те да се уз то наведе број документа, година односно број кутије. С обзиром на различите системе који су кориштени при сређивању појединих фондова не наводимо примјер за цитирање архивске грађе, али упућујемо сураднике на књигу М. Гросс, Почеци модерне Хрватске. Неоапсолутизам у цивилној Хрватској и Славонији, Загреб 1985, гдје је питање скраћеног цитирања ефикасно ријешено и у којој сурадници могу потражити инспирацију за стварање властитог сустава цитирања“. У наведеној књизи Мирјана Грос у фуснотама за изворе архивске грађе наводи скраћеницу одређеног архива иза које следе два броја (један је у загради, највероватније година из које

21 My City mreža, „Правила и примери навођења литературе и извора,“ 2005, http:// www.mycity.rs/Istorija/Pravila-i-primeri-navodjenja-literature-i-izvora.html\#p170822 
потиче извор) и, евентуално, назив документа италиком. ${ }^{22}$ На крају књиге наводи изворе и литературу, а у оквиру групе архивске грађе пун назив институција за које су коришћене скраћенице. ${ }^{23}$

Обе препоруке, и истраживачке станице Петница и Мирјане Грос су „логично сналажење у недостатку правила цитирања“, али и потпуно непоуздане. Нису тако ретки случајеви да су библиотеке неких институција - музеја, архива, разних завода, чија је архивска грађа коришћена и цитирана на ова два наведена начина, у неком тренутку преуређиване из различитих разлога: добијање новог или додатног простора или губитак, односно смањење простора, селидбе на нову адресу, реновирање, допуњавање постојећих или сређивања дотле несређених целина архивског материјала. У тим случајевима долази до другачијег распореда грађе и мењања ознака за фасикле, кутије, полице... У свим претходно насталим радовима у којима је цитирана архивска грађа на наведени начин - у суштини по месту смештаја у наведеној библиотеци - такав начин цитирања постаје непоуздан. Једини поуздани податак је назив институције којој припада тако „цитирана“ архивска грађа, под условом да ни институција није променила назив, осим адресе.

Суштина овог трагања односи се пре свега на стандардизацију цитирања изворне архивске грађе, оне која још није дигитализована. Осим споменутих текстова, књига, часописа, зборника, сајтова, у истраживању су обухваћени и закони који су се делом тицали ове теме или упућивали на сродне, као што су Закон о културним добрима, Закон о ауторским и сродним правима, Закон о стандардизацији, разна упутства за коришћење архивске грађе и кодекси при разним архивима и институцијама у Србији.

„Удружење истраживача института хуманистичких наука покренуло је иницијативу за стварање Интернет библиотеке Србије за хуманистичке науке и уметност IBiS. Пројекат се реализује у сарадњи са Националним центром за дигитализацију IBiS, у оквиру пројекта Виртуелна библиотека НЦД-а, чији је уредник Жељко Мијајловић.“24

Mirjana Gross, Počeci moderne Hrvatske, (Zagreb: Globus, 1985), 356-357.

Ibid. - 474.

IbiS - Интернет библиотека Србије за хуманистичке науке и уметност, http://ibis. mi.sanu.ac.rs/index.html, приступ сајту 4. августа 2015. 
Ради презентације и очувања српске научне и културне баштине и културног идентитета у домаћој и међународној јавности, као и унапређења приступа и међународне научне размене, IBiS је створио дигиталну колекцију научних радова са отвореним, бесплатним приступом, према међународним стандардима европских дигиталних библиотека. Ова организација је као један од својих циљева предвидела стварање пет дигиталних збирки различите грађе, међу којима је и „дигитална збирка рукописа и архивске грађе“. Дигитализацијом се тако превазилази проблем недостатка националног стандарда за цитирање архивске грађе, јер ће се она у новом, дигиталном облику цитирати по стандардима за цитирање on line извора. Али - са ризиком могућих недостатака или превида приликом дигитализовања. У међувремену, приликом истраживања неопходно је коришћење и расположиве изворне архивске грађе на застарели, „превазиђени“ и успорени начин, али са смањеним могућностима пропуста уочавања уметнутих докумената различитих формата. Као и прописивање стандарда цитирања приликом коришћења ове врсте извора.

Закључак је да у Србији не постоје национални стандарди који прописују прецизан начин цитирања архивске грађе која није дигитализована или доступна на електронским изворима. Аутори углавном поштују интерна правила или препоруке институција чије су архиве користили или издавача који ће објавити њихов рад.

Може се наћи замерка овом раду као непотребном, посебно на конференцији која се бави дигиталном хуманистиком. Неспорно је да је дигитална хуманистика неопходна и веома корисна у садашњем добу. Њене предности у односу на застареле методе проучавања старих прашњавих материјала су вишеструке и далеко комфорније. Али морамо узети у обзир време које је потребно да се архивски материјали дигитализују или постану доступни, бар научној јавности, на модеран, електронски начин. При томе, не треба занемарити ни време које ће протећи пре него што дође до либерализације ауторских права, која ће вероватно допринети пуној доступности истраживачких домета. Недостатак стандардизације цитирања изворне архивске грађе је последица убрзаног напретка технологије која је и изнедрила дигиталну хуманистику. Примери стандардизације цитирања on 
line извора довољно то илуструју. Било је и таквих констатација као што су „Стандарди су бескорисни“ или „Стандарди су важни само у техничком окружењу“. ${ }^{25}$ Ипак, оно што је преовлађујуће не би смело да занемарује или прескаче нешто што је ретко, али чега има. Овакве ситуације подсећају на нешто што правници називају „претходним питањем“. Правнички речено, то је „питање које није правоснажно решено и тиче се постојања или непостојања правног односа од условљавајућег значаја за исход парнице“. ${ }^{26}$

Примењено на нашу тему, непостојање стандардизације цитирања изворне архивске грађе представља претходно питање за све ауторе истраживачких текстова. Ако се при том руководимо Манифестом за дигиталне хуманистичке науке, у коме се у првој смерници позива на „отворен приступ подацима и метаподацима, који мора бити документован и интероперабилан, и технички и концептуално“,27 јасно је колико је стандардизација важна. Већ следећа смерница која гласи: „подржавамо ширење, размену и слободну модификацију метода, кодова, формата и резултата истраживања" би требало да помогне бржој либерализацији Закона о ауторским и сродним правима, када ће дигитална хуманистика постати свеопште добро. Управо зато, неопходно је решити „претходно питање ", 28 као што се истовремено не би смеле потпуно губити везе са аутентичношћу и додиром изворне архивске грађе, да не бисмо дошли у ситуацију у коју је дошла Витни Третиен са почетка приче.

25 Клер Сибил, „Стандарди за описивање архивских докумената, “Архив, часопис Архива Србије и Црне Горе, 1-2 (2006), 40-56, http://www.arhivyu.gov.rs/index.php?.

26 Vaš advokat Udruženje za besplatnu pravnu pomoć, „Predhodno (preducijalno) pitanje,“ http://vasadvokat.com/predhodno-preducijalno-pitanje, приступ сајту 8. августа 2015.

27 THATCamp Paris, „Manifest za digitalne humanističke nauke," 2011, http://tcp.hypotheses.org/503. Ibid. 


\section{Литература}

Berry, David M. “Дигитална хуманистика: први, други, трећи талас." Центар за дигиталне хуманистичке науке. Датум објављивања 5. марта 2011. http:// www.humanistika.org/?p=487.

„Библиотека ДКСг - Водич за цитирање.“ Дом културе Студентски град. http:// www.dksg.rs/biblioteka/vodicZaCitiranje/uvod.html. Приступ сајту 5. августа 2015.

„Цитирање литературе и библиографски алати.“ Универзитет у Београду Универзитетска библиотека „Светозар Марковић“. Последњипутажурирано 11. августа 2015. http://unilib.libguides.com/content.php?pid=441025\&sid=3611085.

Gross, Mirjana. Počeci moderne Hrvatske. Zagreb: Globus, 1985.

IbiS - Интернет библиотека Србије за хуманистичке науке и уметност, http://ibis. mi.sanu.ac.rs/index.html, приступ сајту 4. августа 2015.

“ISAD (G) Општи међународни стандард за опис архивске грађе." International Council of Archives, http://www.ica.org/download.php?id=1695. Приступ сајту 6. августа 2015.

„ISO 999:1996 Information and documentation - Guidelines for the content, organization and presentation of indexes." Архив Југославије. http://www.arhivyu.gov. rs/active/sr-cyrillic/home/glavna_navigacija/za_arhiviste/standardi/opsti_ standardi.html. Приступ сајту 6. августа 2015.

Милић, Наташа. „Цитирање литературе унаучном раду,“Ју Народна иуниверзитетска библиотека Републике Српске. http://nub.rs/fileadmin/informacione_usluge/ citiranje/Natasa_Milic-Citiranje_literature_u_naucnom_radu.pdf. Приступ сајту 7. августа 2015.

My City mreža. „Правила и примери навођења литературе и извора.“ 2005. http://www.mycity.rs/Istorija/Pravila-i-primeri-navodjenja-literature-i-izvora. html\#p170822.

Порубовић-Видовић, Оливера и Сузана Срндовић. „Стандарди и препоруке које се односе на делатности у архив." Архив, часопис Архива Србије и Црне Горе. 1-2 (2007): 9-26. http://www.arhivyu.gov.rs/index.php?.

Сабовљев, Драгана. „Чикаго стил библиографског цитирања." Панчевачко читалиште, часопис Градске библиотеке Панчево. 13 (2008): 111 - 115. http://www.citaliste.rs/citaliste_files/sabovljev_cikago_stil.pdf.

Сибил, Клер. „Стандарди за описивање архивских докумената.“ Архив, часопис Архива Србије и Црне Горе. 1-2 (2006). http://www.arhivyu.gov.rs/index.php?.

Сузић, Никола. „Правила писања научног рада: АПА и други стандарди.“ Panevropski Apeiron univerzitet. https://www.google.rs/search?q=nikola+suzi\%C4\%87\&sites earch=apeiron-uni.eu\&gws_rd=cr,ssl\&ei=IGvQVdGhK8i6UY67gJgL. Приступ сајту 7. августа 2015.

THATCamp Paris. „Manifest za digitalne humanističke nauke.“ 2011. http://tcp. hypotheses.org/503. 
Trettien, Whitney. „Да ли је Гугл добар за историју? Повратак случају Пипс.“ Центар за дигиталне хуманистичке науке. Датум објављивања 21. марта 2010. http:// www.humanistika.org/?p=348.

„Upute suradnicima.“ Radovi, 29 (1997). http://hrcak.srce.hr/file/77076. Приступ сајту 7. августа 2015.

„Упутство за припрему рукописа за штампу.“ Јужнословенски филолог LXV (2009): 656-657. https://books.google.rs/books?id.

Vaš advokat Udruženje za besplatnu pravnu pomoć. „Predhodno (preducijalno) pitanje.“ http://vasadvokat.com/predhodno-preducijalno-pitanje. Приступ сајту 8. августа 2015.

„Закон о културним добрима.“ (Службени гласник РС", бр. 71/94). Народна библиотека Србије, Закони. Приступ сајту 5. августа 2015. https://www.nb.rs/ view_file.php?file_id=286.

\title{
Vesna Arsić \\ Branka Dragosavac
}

City Library Belgrade

\section{DIGITALIZATION AND QUOTATION STANDARDIZATION}

\begin{abstract}
Summary
This paper focuses on disregarded kind of issues which are appearing over and over again during certain scientific researches. A new era and different way of communication - electronic communication which is easier and faster, initiated a different way of scientific researches based on the newest sources - digital sources. Positive effects of that kind of scientific researches are easier and faster materials researching that is easy to access at any time and from any place. That's how the new, digital way of research, have been spread in new, digital era. Digital sources that have not been incurred (born) in digital form, but created by digitizing material, authentic documents, beside keeping certain materials, especially archival, from decomposure and space saving, surely are providing availability, which is in accordance with trends of not only scientific research institutions, but individuals also. Even the strict copyrights and related laws have been liberalized increasingly in the field of science, in European countries mostly. Online sources are all represented in the footnotes and the literature of scientific papers, and accordingly, have standardized quotation method and literature quotation in all four known quotation styles. However, to fully digitalize it will take many years and during
\end{abstract}


that time many more non-digital archive material won't be available for research. In the meantime, especially senior researchers, can't rely on archive listing standards. For now, the method of quotation archival material depends on individual archives' rules (tag signature in certain archives) or on the recommendations of the forums, as one of them which have already been found on the forum of My City networks, originates from Petnica Research Station, from more then 10 years ago. Digitalized materials are the result of digital humanity challenges, but until the completion of this very valuable process for science and civilization in general, it should not loose link with the authenticity of archival material, because it has been already reflected as a lack of quotation standardization, which is indispensable element of any well-argued scientific work.

Key words: digitalization, scientific research, quotation, archival material 